\title{
PENERAPAN MENTAL KOGNITIF ISLAM DAN PSIKOSOSIAL ISLAM DALAM MENCEGAH PERILAKU LGBT PADA REMAJ A MUSLIM PEKANBARU
}

\author{
${ }^{1}$ KHAIRIL ANWAR, ${ }^{2}$ SRI WAHYUNI \\ ${ }^{1}$ Program Pasca Sarjana UIN Sultan Syarif Kasim Riau \\ ${ }^{2}$ Fakultas Psikologi UIN Sultan Syarif Kasim Riau \\ eying74@yahoo.com
}

\begin{abstract}
The research aims to assist young people in finding their identity as Muslim youths in the form of increased knowledge of LGBT teens about the dangers so that teens can prevent itself from LGBT effect through proper attitude toward LGBT and ultimately increase the assertiveness in refusing calls to LGBT. The target group of the activities are strategic in high school students in Pekanbaru. Selection of this group for high school students are often targeted for LGBT actors in the search for a young couple. In addition, high school students who have been trained are expected to disseminate their knowledge to other young fellow. In this study it was found that there are significant differences in the level of knowledge of LGBT between pretest and posttest (Z-test $=-3.276, p<0.05)$. LGBT knowledge increased after training. That is, the mental training of cognitive and psychosocial effective to improve participants' knowledge about LGBT.
\end{abstract}

Keywords : LGBT, Kognitif Islam, Remaja.

\section{PENDAHULUAN}

Beberapa tahun terakhir
kasus LGBT (Lesbian, Gay,
Biseksual, dan Transgender)
semakin marak terjadi, bahkan
pelaku LGBT semakin berani
menunjukkan jati dirinya. Pada
mulanya, pelaku LGBT dianggap
gangguan jiwa, dosa dan tidak
diterima di masyarakat. Pada buku
The Diagnostic and Statistical of

Mental Disorders (DSM) yang digunakan oleh para psikolog dan psikiater sebagai acuan dalam mendiagnosa gangguan mental, pada mulanya yaitu DSM I dan II mengklasifikasikan LGBT sebagai gangguan mental. Namun, selama bertahun-tahun terjadi perdebatan yang panjang dan penuh politik antara psikiater dan psikolog yang pro dan kontra terhadap LGBT. Akhirnya, pada DSM III dan IV, 
Khairil Anwar, Penerapan Mental Kognitif Islam dan Psikososial Islam Dalam Mencegah Prilaku LGBT Pada Remaja Muslim Pekanbaru

LGBT dikeluarkan dari klasifikasi gangguan mental. Dan diketahui ternyata lima orang penyusun buku DSM adalah homoseksual dan lesbian, dan sisanya dua orang adalah aktivis LGBT (Azwar, 2016). Namun demikian, Ketua Seksi Religi Spiritual dan Psikiatri (RSP) pada Perhimpunan Dokter Spesialis Kedokteran Jiawa Indonesia (PDSKJI), dr Fidiansjah SpKJ mengungkapkan bahwa DSM IV hanya berlaku untuk Negara Amerika Serikat saja. Lebih lanjut, beliau mengatakan bahwa keilmuwan psikiatri tidak dapat lepas dari masalah religiusitas (Republika, 2016).

Tidak hanya mengeluarkan LGBT dari DSM, namun sampai saat ini, pelaku LGBT dan Lembaga Swadaya Masyarakat (LSM) terus menuntut kepada pemerintah untuk dilegalkan. Ada beberapa Negara yang melegalkan LGBT dan pernikahan sejenis antara lain Belanda, Belgia, Spanyol, Kanada, Afrika Selatan, Norwegia, Swedia, Meksiko, Islandia, Argentina, Uruguay, Selandia Baru, Perancis, Denmark, Inggris, Wales, Skotlandia, Vietnam, Brazil, Luksemburg, Finlandia, Irlandia, dan Amerika Serikat (Sindonews.com, 2016)

LGBT sebenarnya sudah terjadi semenjak zaman Nabi Luth, as., sebagaimana yang difirmankan Allah SWT dalam Al-Qur'an surat AIA'raaf ayat $80-84$, berikut ini:

Dan (Kami juga telah mengutus) Luth (kepada kaumnya). (Ingatlah) tatkala dia berkata kepada mereka: "Mengapa kamu mengerjakan perbuatan faahisyah itu, yang belum pernah dikerjakan

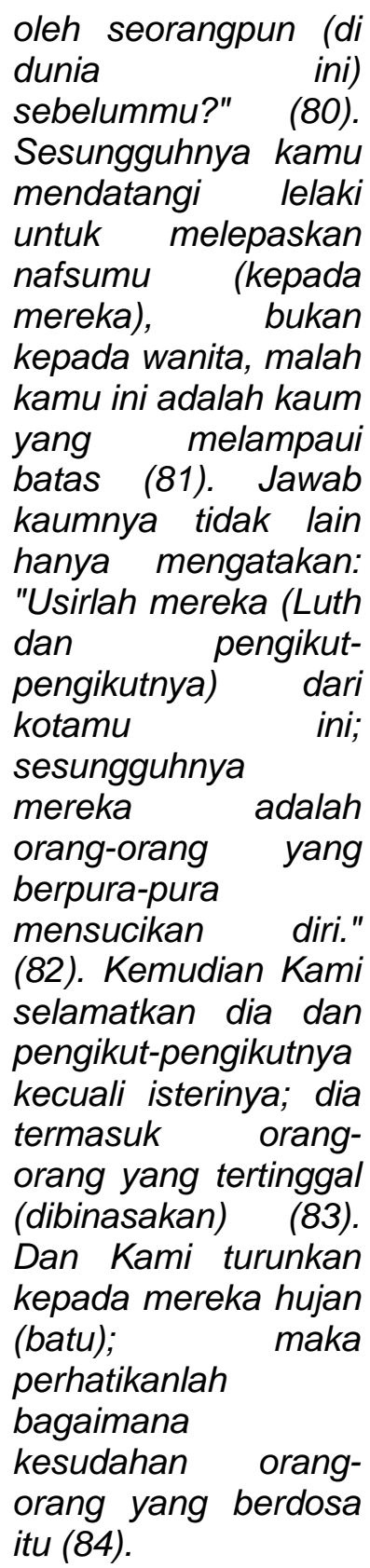

Pada QS. Al-A'raaf ayat 80 84 di atas menjelaskan bahwa Allah SWT mengutus Nabi Luth, as. pada kaum yang suka melakukan hubungan seksual sesama jenis. Nabi Luth, as. sudah berkali-kali memperingatkan kaumnya untuk tidak melakukan perbuatan tersebut namun kaumnya malah mengusir Nabi Luth. Akhirnya Allah SWT memberikan hukuman kepada kaum 
Nabi Luth, as. tersebut dan menyelamatkan orang-orang yang mengikuti dakwah Nabi Luth, as. untuk meninggalkan perilaku homoseksual dan lesbian (Shihab, 2001).

LGBT tidak hanya menjadi perilaku seksual menyimpang yang dilarang oleh agama, namun secara ilmiah perilaku LGBT juga terbukti menjadi salah satu penyebab munculnya penyakit HIV AIDS dan penyakit menular seksual. Dari tahun $1985-201154,7 \%$ dari 69.856 laki-laki homoseksual di Kanada positif HIV (Public Health Agency of Canada, 2013). Selain itu, pelaku LGBT akan mengalami konflik internal maupun konflik eksternal. Konflik internal berupa pergulatan pribadi seputar perasaan akan identitas diri dan seksual, sedangkan konflik eksternal berupa masalah yang timbul didalam lingkungan keluarga dan sosial (Kusuma, 2012), kekerasan terhadap pasangan karena adanya rasa cemburu, pembunuhan, bahkan bunuh diri (Suicide Prevention Resource, 2008)

Semakin hari, LGBT semakin menggurita bahkan mengancam generasi muda. Pelaku LGBT tidak hanya mencari orang yang sudah dewasa sebagai pasangan, namun juga mulai membidik remaja untuk menjadi pasangannya, yang dikenal sebagai istilah brondong. Kasus LGBT ini juga terjadi di UIN Suska Riau, yaitu salah satu mahasiswa memiliki penyimpangan seksual (homoseksual). Karena merasa tidak diterima di lingkungan akhirnya mahasiswa tersebut memilih pindah agama yang dianggapnya lebih menerima LGBT.

Begitu besar bahaya LGBT, maka Pekanbaru sebagai salah satu kota besar yang sedang menuju menjadi kota metropolis madani perlu mewaspadai virus LGBT ini.
Hal ini karena Pekanbaru memiliki generasi muda (remaja) yang cukup banyak. Pada masa remaja, terjadi proses perkembangan pencarian jati diri dan sering dikenal sebagai masa penuh gejolak (Papalia, Old \& Feldman, 2008). Pada masa remaja ini terjadi, seorang anak merasa dirinya sudah besar dan ingin mandiri, namun sesungguhnya remaja masih membutuhkan pengawasan dari orangtua.

Oleh karena itu, sangat penting adanya pembetukan jati diri remaja. Remaja yang memahami siapa dirinya dan apa tujuan dari hidupnya akan mampu menjalani kehidupaannya dengan penuh makna dan bahagia. la akan fokus dalam mencapai cita-cita, berorientasi kepada prestasi, dan tidak mudah terpengaruh oleh perilaku-perilaku negatif. Sebaliknya, remaja yang tidak mampu menemukan jati dirinya akan menjadi oleng dan terombangambing sehingga mudah terbawa oleh pengaruh negatif, termasuk perilaku LGBT.

Berbagai pihak menunjukkan kepedulian terhadap bahaya LGBT. Majlis Ulama Indonesia (MUI) melakukan pendataan di setiap wilayah yang bertujuan untuk mengantisipasi masuknya paham sesat dan LGBT yang dapat merusak aqidah dan mental masyarakat (Republika, 2016). Sebagai ilmuwan, perlu memikirkan suatu usaha guna pencehan LGBT berkembang khususnya di kalangan remaja. Oleh karena itu, perlu kiranya dilakukan suatu program prevensi guna membentengi remaja terhadap perilaku LGBT ini. Program prevensi yang akan dilakukan adalah Pelatihan Penerapan Mental Kognitif Islam dan Psikososial Islam. Kegiatan dilakukan berbentuk pelatihan terapi perilaku kognitif 
Khairil Anwar, Penerapan Mental Kognitif Islam dan Psikososial Islam Dalam Mencegah Prilaku LGBT Pada Remaja Muslim Pekanbaru

(cognitive behavior therapy). Kegiatan ini diharapkan mampu meningkatkan pengetahuan remaja tentang dampak negatif LGBT, mengarahkan remaja untuk memiliki sikap yang tepat dalam menghadapi perilaku LGBT dan meningkatkan asertivitas dalam menolak ajakan perilaku LGBT.

\section{PERSPEKTIF LGBT DALAM TEORI}

LGBT merupakan singkatan dari Lesbian, Gay, Biseksual, dan Transgender Transgender. Homoseksual merupakan ketertarikan secara seksual pada jenis kelamin yang sama. Laki-laki yang tertarik sesama laki-laki disebut sebagai gay, dan perempuan terhadap perempuan disebut lesbian. Biseksual adalah ketertarikan secara seksual terhadap perempuan dan laki-laki sekaligus (Mastuti, Winarno \& Hastuti, 2012). Transgender adalah istilah yang digunakan untuk menjelaskan orang yang berpikir, merasa, dan berperilaku berbeda dengan jenis kelamin yang ditetapkan saat lahir (APA, 2006).

\section{Perkembangan LGBT di Indonesia}

Oetomo, dkk. (2013) menjelaskan sejarah LGBT di Indonesia pada laporan Dialog Komunitas LGBT Nasional Indonesia yang diselenggarakan pada 13-14 Juni 2013 di Bali. Homoseksual mulai muncul di kota-kota besar di Indonesia pada beberapa dasawarsa awal abad ke-20. Pada tahun 1960-an kelompok pelaku LGBT di Indonesia mulai membentuk advokasi yang diberi nama Himpunan Wadam Djakarta (Hiwad), yang difasilitasi oleh Gubernur DKI Jakarta pada waktu itu, Jenderal Marinir Ali Sadikin. Istilah wadam (wanita Adam) diperkenalkan sebagai pengganti kata banci atau bencong yang bersifat menghina. Istilah ini kemudian pada tahun 1978 diganti dengan waria (wanita pria) karena Majelis Ulama Indonesia menilai tidak patut nama seorang nabi (Adam) dijadikan bagian pada istilah untuk kaum laki-laki yang mengekspresikan jendernya dengan cara yang lebih menyerupai perempuan. Organisasi yang berfungsi sebagai ruang sosial budaya yang aman ini, dengan cepat disusul oleh organisasi serupa di kota-kota besar lain.

Kalangan pria homoseksual pada tahun 1982 mulai merintis usaha pengorganisasian dengan mendirikan Lambda Indonesia. Pada tahun 1986 beberapa lesbian Jakarta sempat mendirikan Persatuan Lesbian Indonesia (Perlesin), karena merasa terdorong oleh perkawinan dua wanita pada tahun 1981 yang mendapatkan liputan media massa dan terinspirasi dari keikutsertaan mereka di organisasi Lambda Indonesia cabang Jakarta. Organisasi ini tidak terkenal secara luas sebagaimana halnya organisasi gay, dan hanya bertahan kurang dari satu tahun.

Kepimpinan nasional Lambda Indonesia juga sempat mengalami kemunduran pada tahun 1986, meskipun beberapa cabang organisasi masih melanjutkan kegiatan. Pada tahun 1985, cabang Yogyakarta membentuk dirinya sebagai organisasi mandiri setempat dengan nama Persaudaraan Gay Yogyakarta (PGY) yang juga menerbitkan majalah Jaka. Beberapa mantan aktivis cabang Lambda Indonesia di Surabaya mendirikan Kelompok Kerja Lesbian dan Gay Nusantara, disingkatkan 
menjadi GAYa NUSANTARA, dan menerbitkan majalah yang juga diberi nama GAYa NUSANTARA. Organisasi ini memiliki tujuan antara lain mendorong pendirian komunitas dan organisasi di berbagai daerah di Indonesia. Selanjutnya PGY mengganti namanya pada tahun 1988 menjadi Indonesian Gay Society, dan melanjutkan publikasi majalah Jaka-Jaka serta menyelenggarakan pertemuan dan diskusi di Yogyakarta secara berkala, yang tidak hanya menarik pria gay setempat tetapi juga peserta lain dari berbagai daerah di Jawa Tengah.

Pada awal dasawarsa 1990an, meningkatnya liputan media tentang HIV yang hampir selalu menyebutkan tentang pria homoseksual dan waria, membuka peluang lain bagi beberapa organisasi yang tampil di media massa untuk menjangkau konstituen mereka. Dalam beberapa tahun awal dasawarsa tersebut berdiri berbagai organisasi di Bandung, Jakarta, Pekanbaru, Denpasar, Malang dan Makassar. Para lesbian dan pria transgender juga berusaha mengorganisir diri lagi di Jakarta, Makassar dan Singaraja. Chandra Kirana, yang merupakan kumpulan lesbian di Jakarta, membuat majalah sendiri, yaitu Gaya Lestari, yang selama sekitar dua tahun terbit sebagai sisipan dalam majalah GAYa NUSANTARA.

Menjelang akhir tahun 1993, terdapat cukup banyak organisasi dan aktivis individu sehingga mampu menyelenggarakan Kongres Lesbian dan Gay Indonesia pertama (KLGI I) di Kaliurang, dekat Yogyakarta. Semakin banyak organsasi didirikan di berbagai wilayah Indonesia, yaitu: Medan, Batam, Ambon dan lain sebagainya. Diadakan dua kongres lagi, yaitu: KLGI II di Lembang, dekat
Bandung (tahun 1995) dan KLGI III di Denpasar (tahun 1997). Jumlah peserta pertemuan berkembang semakin besar, terdiri dari wakilwakil organisasi, aktivis individu dan mereka yang berperan aktif dalam berbagai kaukus organisasi kesehatan dan hak-hak yang seksual dan reproduksi. Namun hanya sedikit kaum lesbian yang berpartisipasi dan sama sekali tidak ada aktivis transgender yang hadir. Kongres 1997 merupakan yang pertama mendapatkan liputan koran daerah.

Pada pada awal 2007 berdiri Jaringan Gay, Waria dan Laki-Laki yang Berhubungan Seks dengan Laki-Laki Lain (GWL-INA) dengan dukungan dari mitra kerja baik nasional, bilateral maupun internasional. Pada Januari 2008, setelah Konferensi International Lesbian, Gay, Bisexual, Trans and Intersex Association (ILGA) tingkat Asia yang ke-3 di Chiang Mai, Thailand, enam organisasi LGBT yang berkantor pusat di Jakarta, Surabaya dan Yogyakarta bergabung untuk memperkuat gerakan mereka. Langkah ini menjadi awal Forum LGBTIQ (Lesbian, Gay, Bisexual, Transgender, Intersex \& Queer) Indonesia.

\section{SIKAP TERHADAP LGBT}

Sikap merupakan salah satu unsur kepribadian yang harus dimiliki seseorang yang bertujuan untuk menentukan tindakan dan perilaku terhadap suatu objek yang disertai dengan perasaan positif dan negatif (Azwar, 2002). Formulasi sikap itu dikaitkan sebagai afek positif dan afek negatif yang dikaitkan dengan suatu obyek psikologis, baik objek/subjek yang positif maupun negatif (Suharyat, 2009). 
Khairil Anwar, Penerapan Mental Kognitif Islam dan Psikososial Islam Dalam Mencegah Prilaku LGBT Pada Remaja Muslim Pekanbaru

Jadi sikap terhadap LGBT adalah penilaian individu terhadap perilaku LGBT, dan sikap ini yang akan menentukan tindakan individu terhadap perilaku LGBT tersebut.

\subsection{Aspek-aspek Sikap}

Sikap memiliki 3 komponen yakni: kognitif, afektif, dan konatif (Azwar, 2002):

1) Komponen kognitif yaitu komponen sikap yang berkaitan dengan penilaian individu terhadap obyek atau subyek. Informasi yang diterima oleh individu dianalisa, sintesis, dan dievaluasi sehingga akan menghasilkan nilai baru yang akan diadaptasikan terhadap pengetahuan yang sudah dimiliki sebelumnya.

2) Komponen afektif, yaitu perasaan atau emosi individu terhadap objek atau subjek, dan hal ini berkaitan dengan hasil penilaiannya secara kognitif.

3) Komponen konatif, yaitu suatu dorongan dari dalam diri individu untuk melakukan suatu tindakan sesuai dengan keyakinan, keinginan, dan perasaannya.

\section{PE NDE KATAN COG NITIVE BEHAVIOR THERAPY (CBT)}

Terapi perilaku adalah suatu tritmen psikologis yang bertujuan untuk mengubah perilaku manusia yang dapat diamati dan diukur (Curwen \& Ruddel, 2011). Terapi kognitif adalah suatu pendekatan yang mengombinasikan penggunaan teknik kognitif dan perilaku untuk membantu individu memodifikasi mood dan perilakunya dengan mengubah pikiran yang merusak diri (Szymanska \& Palmer, 2011). Dan terapi kognitf perilaku (CBT) adalah suatu bentuk tritmen psikologis yang memadukan antara terapi kognitif dan perilaku yang berfokus pada pikiran, perasaan, dan perilaku klien.

\section{ME NTAL-KOGNITIF ISLAM}

Istilah mental-kognitif Islam diuangkapkan pertama kali oleh Shariati (1995) ketika menjelaskan tentang menurunnya kualitas umat Islam. Namun demikian, beliau tidak menjelaskan definisi konsep secara jelas terhadap istilah ini. Selanjutnya Anwar (2014) mencoba mendefinisikan mental-kognitif Islam berdasarkan definisi kognitif dan definisi mental, yaitu suatu struktur internal manusia yang melahirkan persepsi, introspeksi, memori, kreativitas, imaginasi, konsep, keyakinan, kemauan, dan emosi sebagai suatu kesatuan cara berfikir yang berlandaskan Islam.

\subsection{Domain Mental-Kognitif Islam}

Adapun domain-domain tahapan mental-kognitif Islam ada empat yaitu (Anwar, 2014):

1. Ilmu ketauhidan yang dibentuk dari konstruk rukun iman, hakikat yang pertama, keesaan yang mutlak, kesempurnaan tertinggi qada dan qadar, amal sebagai sendi keimanan, iman dan dosa, pertikaian, nubuwah, kekekalan atau keabadian. Tauhid merupakan landasan kebahagiaan, akhlak yang mulia, ketenangan jiwa dan batin, tauhid membebaskan jiwa dari pengaruh kekuasaan orang lain, tauhid 
menumbuhkan keyakinan tentang rezeki, tauhid memberikan kehidupan yang baik, hakikat syirik dan amar ma'ruf nahi munkar.

2. Hukum Islam yaitu sumber hukum Islam, dasar Islam, konsep thoharoh, konsep hukum, konsep keadilan, konsep syura, konsep jama'ah, konsep jenayah, konsep sahsiyah, konsep muamalah, konsep mu'asyarah, Islam dan hukum universal, konsistensi dan fleksibiliti hukum Islam.

3. Konsep pengetahuan Islam yaitu Al Qur'an dan ilmu pengetahuan, hadits dan ilmu pengetahuan, ekonomi Islam, pengurusan Islam, konsep kesehatan dan keselamatan Islam, sains Islam, modernisasi Islam, tokoh saintis Islam, kemajuan sains Islam, sains dan materialisma, sains dan westernisma.

4. Sejarah Islam yaitu falsafah sejarah, sejarah dan kepentingan dakwah, sejarah dalam Al Qur'an, sejarah rasul, sejarah sahabat, sejarah peradaban Islam, sejarah tokoh kontemporari Islam, sejarah konflik dalam Islam.

\section{PSIKOSOSIAL ISLAM}

Psikososial didefinisikan sebagai hubungan yang dinamik antara psikologi dan pengaruh sosial dan di antara keduanya saling mempengaruhi. Kedua, komponen tersebut merupakan hal yang penting untuk proses perkembangan individu. Gangguan psikososial terjadi apabila terdapat ketidakseimbangan antara kedua komponen di atas yang menyebabkan perubahan dalam kehidupan (Smet, dalam Anwar, 2014)

Psikososial sebagai istilah yang difokuskan untuk mempelajari dan menerangkan tingkah laku individu sebagai fungsi dari rangsangan-rangsangan psikologikal dan sosial, maka psikososial Islam dapat dirumuskan definisinya sebagai suatu pandangan yang melibatkan persepsi, motivasi, kepercayaan dan interaksi sosial yang berasaskan ajaran Islam untuk melihat suatu permasalahan sosial yang akan mempengaruhi atribut tingkah laku individu di dalam masyarakat (Anwar, 2014)

\subsection{Domain-domain Psikososial Islam}

Domain-domain psikososial Islam dibagi menjadi tiga, yaitu (Anwar, 2014):

1. Instrinsik Islam, yaitu mengenali konsep khalifah, keunggulan diri, mengenali dan membangun misi, menciptakan wawasan, komitmen, jati diri, kecerdasan, cita-cita, keberuntungan,

kreativitas, obsesi dan ibadah.

2. Sikap dan sudut pandang sosial yaitu prasangka, saling percaya, saling mendukung, kerjasama, terbuka, penampilan terbaik, defensif, tertutup, menahan informasi (terdiri daripada: nonkooperatif dan penampilan turun), prinsip-prinsip hidup (terdiri dari: spiritual 
Khairil Anwar, Penerapan Mental Kognitif Islam dan Psikososial Islam Dalam Mencegah Prilaku LGBT Pada Remaja Muslim Pekanbaru

kapital dan material kapital), pengalaman (terdiri dari: positif dan negatif), kepentingan (terdiri dari: jangka panjang dan jangka pendek), sudut pandang (wisdom) berdasarkan aturan dari Allah SWT dan Rasul-Nya, perbandingan (standard nilai tinggi, standard nilai rendah, objektif dan subjektif), dan literatur (agama, falsafah dan ilmu).

3. Dakwah dan nilai diri yaitu iman dan yakin yang betul, menjadi khalifah untuk berdakwah, ihsan (tawajuh), intisab, ikhlas (ridha), mujahadah nafsi, yakin pada kalimat thoyyibah, solat khusyu', ilmu ma'a zikir, ikromul muslimin, tashihunniyat dan dakwah wat tabligh.

\section{Asertivitas}

Asertif adalah menjadi diri sendiri, dengan mempertimbangkan opini dan perasaan sendiri, dan bukan berdasarkan orang lain, mengungkapkan secara jelas tentang harapan dan meminta dengan tegas apa yang menurutnya benar (Williams, 2000).

\subsection{Aspek-aspek Asertivitas}

Menurut Eisler, dkk. (dalam Marini dan Andriani, 2005) ada tujuh komponen asetivitas, yaitu:

1) Compliance, yaitu usaha seseorang untuk tidak sependapat atau menolak orang lain, yang ditandai dengan keberanian seseorang untuk mengatakan tidak jika hal tersebut memang tidak sesuai dengan keinginannya.

2) Duration to Reply, yaitu lamanya waktu yang dibutuhkan seseorang untuk mengatakan apa yang dikehendakinya, dengan menerangkannya kepada orang lain.

3) Loudness, yaitu berbicara dengan suara yang keras dan jelas, namun tidak berteriak.

4) Request for New Behavior, yaitu meminta orang lain untuk mengubah perilakunya ke arah yang lebih baik, mengungkapkan tentang fakta atau perasaan dalam memberikan saran kepada orang lain, dengan tujuan agar situasi berubah sesuai dengan yang diinginkan.

5) Affect, yaitu berbicara dengan fluktuasi yang sedang, bukan dengan nada yang keras, dan bukan merupakan respon yang monoton dan emosional.

6) Latency of Response, yaitu adanya jeda sesaat sebelum menjawab atau memberikan respon terhadap pembicaraan orang lain.

7) Non Verbal Behavior, terdiri dari:

a. Kontak mata, yaitu memandang orang yang diajak bicara secara wajar

b. Ekspresi muka, yaitu ekspresi wajah sesuai dengan pesan 


\begin{abstract}
yang disampaikan.

c. Jarak fisik, yaitu mengatur jarak fisik yang pantas saat berbicara, jangan terlalu dekat maupun terlalu jauh.

d. Sikap badan, yaitu sikap badan yang tegak saat bicara dengan orang lain.

e. Isyarat tubuh, yaitu pemberian isyarat tubuh dengan gerakan tubuh yang sesuai dapat menambah keterbukaan, kepercayaan diri, dan memberikan penekanan terhadap apa

A. Identifikasi dan dikatakan. Masalah

Berdasarkan penjelasan pada analisa situasi di atas, maka dapat dirumuskan suatu masalah bahwa apakah pelatihan penerapan mental kognitif Islam dan psikososial Islam dapat mencegah perilaku LGBT?
\end{abstract}

\section{METODE PENELITIAN}

\section{Kerangka Pemecahan Masalah \\ Metode yang digunakan} dalam memecahkan masalah LGBT dalam penelitian ini adalah dengan menyelenggarakan pelatihan "Penerapan Mental Kognitif Islam dan Psikososial Islam dalam Mencegah Perilaku LGBT pada Remaja Muslim Pekanbaru (Pendekatan Cognitive Behavior Therapy Islam)".

Pelatihan ini dilakukan dalam lima sesi:

\section{a. Sesi l: Pengetahuan tentang LGBT dan bahayanya terhadap perkembangan remaja}

Pada sesi I ini, trainer menjelaskan tentang definisi, macam-macam perilaku LGBT, dan dampak negatif LGBT terhadap perkembangan dan masa depan remaja.

\section{b. Sesi II : Who Am I}

Sesi II ini bertujuan untuk mengajak peserta pelatihan mengetahui siapa dirinya, apa kelebihan dan kekurangan yang dimilikinya, dan apa tujuan hidupnya.

\section{c. Sesi III : Terapi Kognitif Perilaku Mental Kognitif Remaja Muslim}

Pada sesi III ini, trainer mengajak peserta untuk mengidentifikasi keriteria mental-kognitif remaja muslim yang seharusnya. Setelah itu remaja melakukan refleksi diri apakah kriteria mentalkognitif remaja muslim tersebut sudah ada pada dirinya. Kemudian trainer menjelaskan tentang domain atau kriteria mental-kognitif remaja muslim yang terlihat dari kualitas keimanan, penerapan hukum-hukum Islam, konsep ilmu pengetahuan dalam Islam, dan sejarah Islam. Sesi ini diharapkan peserta mampu memahami mental-kognitif remaja muslim dan mengaplikasikannya dalam kehidupan sehari-hari sehingga menjadi muslim yang kaffah dan tidak mudah 
Khairil Anwar, Penerapan Mental Kognitif Islam dan Psikososial Islam Dalam Mencegah Prilaku LGBT Pada Remaja Muslim Pekanbaru

terpengaruh oleh hal-hal yang negatif termasuk LGBT.

d. Sesi IV : Terapi Kognitif Perilaku Psikososial Remaja Muslim

Pada sesi ini, trainer menjelaskan tentang psikososial Islam yang berisikan persepsi, motivasi, kepercayaan dan interaksi sosial yang berasaskan ajaran Islam untuk melihat suatu permasalahan sosial yang akan mempengaruhi atribut tingkah laku individu di dalam masyarakat. Trainer mengajak peserta untuk memahami bahwa manusia diciptakan untuk menjadi khalifah, mengenali potensi diri dan memiliki tujuan yang jelas dalam hidup. Selanjutnya, trainer mengajak peserta berdiskusi tentang bagaimana bersikap dan memiliki sudut pandang dalam hidup bermasyarakat, dan melakukan amal ma'ruf nahi munkar secara ikhlas guna mencegah perilakuperilaku yang menyimpan yang terjadi di masyarakat, salah satunya LGBT.

\section{e. Sesi V : Refleksi Diri}

Pada sesi terakhir ini, peserta melakukan refleksi diri tentang bahaya LGBT dan tindakan-tindakan yang dapat dilakukan oleh peserta guna mencegah diri dan teman-teman di lingkungan untuk tidak terjebak terhadap perilaku LGBT.

\section{Kelompok Sasaran Antara Yang Strategis}

Kelompok sasaran antara yang strategis dalam kegian ini adalah siswa SMU di Pekanbaru. Pemilihan kelompok ini karena siswa SMU sering menjadi sasaran bagi pelaku LGBT dalam mencari pasangan yang masih muda. Selain itu, siswa SMU yang sudah mengikuti pelatihan diharapkan dapat menyebarkan ilmu pengetahuan yang dimilikinya kepada teman sesama remaja lainnya.

\section{Rancangan Evaluasi}

Untuk melihat efektivitas dari kegiatan dilakukan pengukuran baik sebelum (pre test) maupun setelah kegiatan dilakukan (post test). Adapun alat ukur yang digunakan adalah (1) kuesioner pengetahuan tentang LGBT, (2) skala sikap terhadap LGBT, dan (3) skala asertivitas.

Desain penelitian yang digunakan adalah the one-group pretest-posttest design digambarkan sebagai berikut (Shadish, Cook \& Campbell, 2002):

Selanjutya, data dianalisis dengan menggunakan analisis Wilcoxon Signed Rank Test.

\section{HASIL PENELITIAN}

\section{Pelaksanaan Penelitian}

Pelatihan dilaksanakan di Pondok Pesantren "Al-Ihsan Islamic Boarding School" Pekanbaru, Riau. Partisipan penelitian adalah santri putra yang sedang menempuh pendidikan Madrasah Alyah (MA) atau setara dengan SMU. Pada mulanya, jumlah peserta pelatihan adalah 40 orang. Namun pada saat pelaksanaan yang hadir hanya 25 orang karena pada saat yang sama terdapat banyak kegiatan yang dilakukan oleh santri, baik di dalam lingkungan pondok pesantren maupun di luar pondok pesantren. Pada saat pre test, terdapat 25 santri yang mengisi alat ukur, namun 
ketika dilakukan pre tes, hanya 16 orang yang mengisi alat ukur. Hal ini karena beberapa santri harus mengikuti kegiatan selanjutnya sehingga tidak sempat untuk mengisi alat ukur.

\section{Hasil Analisis Data}

\subsection{Pengetahuan tentang LGBT}

Tabel 4.1

Data Deskriptif Pengetahuan LGBT

\begin{tabular}{lccccc}
\hline & N & Mean & $\begin{array}{c}\text { Std. } \\
\text { Deviation }\end{array}$ & Minimum & Maximum \\
\hline Pengetahuan-pretest & 16 & 4.5000 & .51640 & 4.00 & 5.00 \\
Pengetahuan-postes & 16 & 5.3750 & .61914 & 4.00 & 6.00 \\
\hline
\end{tabular}

Tabel 4.2

Hasil Uji Beda Tingkat Pengetahuan

Sebelum dan Setelah Pelatihan Mental Kognitif dan Psikososial Islam

\begin{tabular}{|c|c|c|c|}
\hline Uji Beda & Nilai Z & Nilai Signifikansi & Keterangan \\
\hline $\begin{array}{c}\text { Tingkat Pengetahuan } \\
\text { Pretest \& Posttest }\end{array}$ & $-3,276$ & 0,001 & Signifikan \\
\hline
\end{tabular}

Pada tabel 4.2 ditemukan bahwa terdapat perbedaan yang sangat signifikan tingkat pengetahuan LGBT antara pretest dan posttest. Pengetahuan LGBT meningkat setelah mengikuti pelatihan (tabel 4.1). Artinya, pelatihan mental kognitif dan psikososial Islam efektif untuk mengingkatkan pengetahuan partisipan tentang LGBT.

Pada gambar berikut ini terlihat perubahan tingkat pengetahuan tentang LGBT sebelum dan setelah mengikuti pelatihan mental kognitif dan psikososial Islam untuk setiap partisipan.

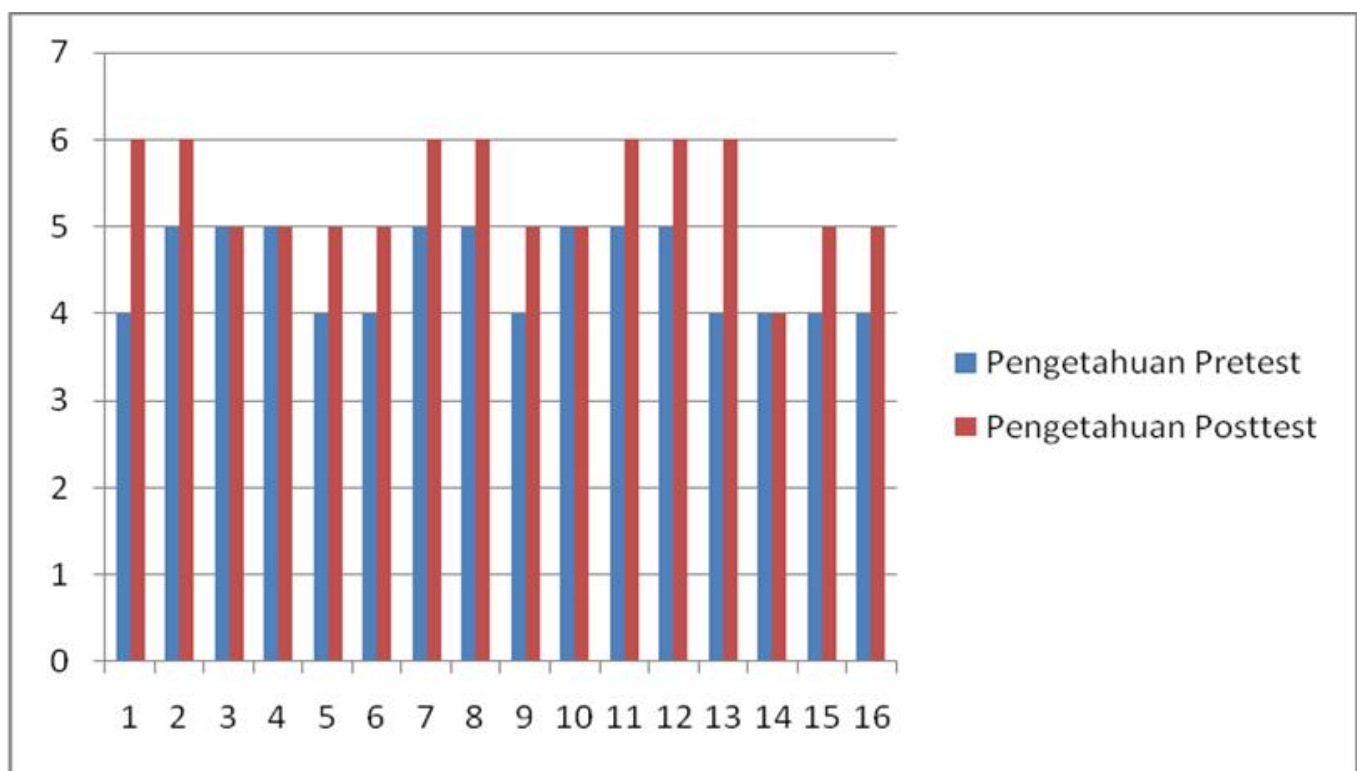

Gambar 4.1

Gambaran Perubahan Tingkat Pengetahuan LGBT Sebelum dan Setelah Mengikuti Pelatihan Mental Kognitif dan Psikososial Islam 
Khairil Anwar, Penerapan Mental Kognitif Islam dan P sikososial Islam Dalam Mencegah Prilaku LGBT Pada Remaja Muslim Pekanbaru

\subsection{Sikap terhadap LGBT}

Tabel 4.3

Data Deskriptif Sikap terhadap LG BT

\begin{tabular}{lccrrr}
\hline & N & Mean & Std. Deviation & Minimum & Maximum \\
\hline Sikap-pretest & 16 & 15.6875 & 1.62147 & 12.00 & 17.00 \\
Sikap- & 16 & 16.0000 & 2.16025 & 9.00 & 17.00 \\
posttest & & & & & \\
\hline
\end{tabular}

Tabel 4.4

Hasil Uji Beda Sikap terhadap LGBT

Sebelum dan Setelah Pelatihan Mental Kognitif dan Psikososial Islam

\begin{tabular}{|c|c|c|c|}
\hline Uji Beda & Nilai Z & Nilai Signifikansi & Keterangan \\
\hline $\begin{array}{c}\text { Sikap Terhadap LGBT } \\
\text { Pretest \& Posttest }\end{array}$ & $-0,996$ & 0,319 & Tidak Signifikan \\
\hline
\end{tabular}

Hasil analisis data menemukan bahwa sikap terhadap LGBT samasama negatif atau partisipan samasama menunjukkan tidak setuju terhadap perilaku LGBT, baik sebelum mengikuti pelatihan maupun setelah mengikuti pelatihan mental kognitif dan psikososial Islam.

\subsection{Perilaku Asertif terhadap LGBT}

Tabel 4.5

Data Deskriptif Perilaku Asertif terhadap LGBT

\begin{tabular}{lccccc}
\hline & N & Mean & $\begin{array}{c}\text { Std. } \\
\text { Deviation }\end{array}$ & Minimum & \multicolumn{2}{c}{ Maximu } \\
\hline Asertif-pretest & 16 & 1.9063 & .17970 & 1.50 & 2.00 \\
Asertif-posttest & 16 & 1.9167 & .14907 & 1.67 & 2.00 \\
\hline
\end{tabular}

Tabel 4.6

Hasil Uji Beda Perilaku Asertif terhadap LGBT

Sebelum dan Setelah Pelatihan Mental Kognitif dan Psikososial Islam

\begin{tabular}{|c|c|c|c|}
\hline Uji Beda & Nilai Z & Nilai Signifikansi & Keterangan \\
\hline $\begin{array}{c}\text { Perilaku Asertif Pretest \& } \\
\text { Posttest }\end{array}$ & $-0,135$ & 0,892 & Tidak Signifikan \\
\hline
\end{tabular}

\section{PE MBAHASAN}

Hasil analisis data pada penelitian ini ditemukan bahwa terdapat perbedaan tingkat pengetahuan tentang LGBT pada partisipan sebelum dan setelah pelatihan mental kognitif dan psikososial 96
Islam. Pengetahuan partisipan tentang LGBT semakin meningkat. Partisipan menjadi semakin tahu tentang definisi LGBT, LGBT menurut perspektif agama Islam, macam-macam ciri perilaku orang LBGT, dampak negatif LGBT bagi 
kesehatan, baik kesehatan fisik maupun psikologis.

Pengetahuan yang diperoleh oleh peserta ini diharapkan mampu membentengi diri peserta secara khusus, dan mampu memberikan penngetahuan kepada teman-teman peserta lainnya tentang LGBT dan bahayanya. Partisipan yang mengikuti pelatihan ini diharapkan mampu menjadi agen pencegah perilaku LGBT di lingkungannya.

Selanjutnya, analisis data tidak menemukan adanya perubahan sikap dan perilaku asertif terhadap LGBT setelah mengikuti pelatihan. Hal ini karena walaupun pengetahuan partisipan tentang LGBT masih sangat terbatas, tetapi partisipan sudah memiliki sikap tidak menyetujui perilaku LGBT dan ketika ada ajakan untuk melakukan perilaku homoseksual, partisipan sudah mampu untuk menolak secara tegas.

Sikap dan perilaku asertif partisipan yang tidak menyetujui LGBT didukung oleh pengetahuan agama yang dimiliki partisipan. Hal ini karena partisipan tinggal di Pondok Pesantren, yang mana sudah diajarkan bagaimana hukuman yang akan diberikan kepada pelaku LGBT. Selain itu, manajemen dan tata kelola pondok pesantren yang modern, misalnya setiap santri tidur di tempat tidur sendiri-sendiri, mandi di kamar mandiri sendiri atau tidak mandi bersama, sehingga meminimalisir perilaku homoseksual. Selain itu, kegiatan pondok yang sangat padat membuat santri tidak memiliki waktu untuk melamun dan memikirkan halhal negatif. Santri pondok pesantren juga bebas dari media (santri tidak dibenarkan memiliki HP dan menonton TV), sehingga santri terbebas dari isu-isu dan propaganda tuntutan legalitas LGBT.

\section{KESIMPULAN DAN SARAN}

\section{Kesimpulan}

Penelitian dengan tema penerapan mental kognitif islam dan psikososial islam dalam mencegah perilaku LGBT pada remaja muslim pekanbaru (pendekatan cognitive behavior therapy Islam) terbukti efektif meningkatkan pengetahuan partisipan tentang perilaku LGBT. Namun tidak terbukti meningkatkan sikap dan perilaku asertif terhadap LGBT, hal ini karena partisipan sudah memiliki sikap yang tidak menyetujui dan menolak perilaku LGBT.

\section{Saran}

Disarankan kepada partisipan yang sudah memiliki pengetahuan tentang LGBT untuk mampu menjadi agen pencegah perilaku LGBT di lingkungannya. Selanjutnya juga disarankan untuk mempertahankan sikap tidak menyetujui dan kemampuan untuk tetap asertif terhadap ajakan melakukan perilaku LGBT.

\section{DAFTAR PUSTAKA}

APA. 2006. Answers to Your Questions About Transgender Individuals and Gender Identity. Washington, DC: APA.

Anwar, K. 2014. Pengaruh Mental Kognitif Islam dan Amalan Sunnah melalui Psikososial Islam dan Estim Kendiri terhadap Kawalan Diri dalam Kalangan Pesalah Laku Remaja di Malaysia. Disertasi. Malaysia: Fakultas Sains dan Sosial Kemanusiaan, UKM 
Khairil Anwar, Penerapan Mental Kognitif Islam dan Psikososial Islam Dalam Mencegah Prilaku LGBT Pada Remaja Muslim Pekanbaru

Azwar, S. 2002. Sikap Manusia: Teori dan Pengukurannya. Yogyakarta: Pustaka Pelajar

Curwen, B. \& Ruddel.P. 2011. Psikoterapi dan Konseling Perilaku. Dalam Editor Palmer. 2011. Konseling dan Psikoterapi. Yogyakarta: Pustaka Pelajar.

Kusuma, P.A. 2012. Konflik Diri dan Persepsi Homoseksual (Lesbian) Terhadap Nilai-nilai Spiritual. Skripsi. Fakultas Psikologi Universitas Muhammadiyah Surakarta.

Marini, L \& Andriani, E. 2005. Perbedaan Asertivitas Remaja ditinjau dari Pola Asuh Orangtua. P sikologia, 1 (2), 46-53.

Mastuti, R.E., Winarno, R.D., \& Hastuti, L.W. 2012. Pembentukan Identitas Orientasi Seksual pada Remaja Gay. Kajian IImiah Psikologi, 2 (1), 194-197.

Oetomo, D., Suvianita, K., Halim, K.S.S., Liang, J., Soeparna, S., \& Surahman, L. 2013. Hidup Sebagai LGBT di Asia: Laporan Nasional Indonesia. Bali: USAID.

Papali, D.E., Old, S.W. \& Feldman, R.D. 2010. Psikologi Perkembangan. Jakarta: Kencana Prenada Media Gorup.

Public Health Agency of Canada. 2013. Population-S pecific HIV/AIDS Status Report. Gay, Bisexual, Two-Spirit and Other Men Who Have Sex With Men. Kanada: Public Health Agency of Canada.

Republika. 2016. MUI Telusuri Masuknya Aliran Sesat dan
LGBT. Dunia Islam. Republika.co.id

Republika. 2016. Pakar: DSM IV Rujukan LGBT Berlakunya di Amrika Saja. Republika.co.id. Shadish, W., Cook, T. \& Campbell, D. (2002). Experimental. \& Quasi-Experimental Designs for Generalized Causal. Inference. Boston: Houghton Mifflin.

Shihab, Q. (2001). Tafsir AlMishbah, Volume 5. Jakarta: Lentera Hati.

Sindonews.com. 2016. Daftar Negara Yang Melegalkan Pernikahan Sejenis dan LGBT.

http://lifestyle.sindonews.com $/ \mathrm{read} / 1082855 / 166 /$ daftarnegara-yang. melegalkanpernikahan-sejenis-dan-lgbt1454594358/1.

Suicide Prevention Resource. 2008. Suicide $\mathrm{R}$ isk and Prevention for Lesbian, Gay, Bisexual, and Transgender Youth. Newton, MA: Education Development Center. Inc.

Syari'ati, A. 1995. Islam Mazhab Pemikiran dan Aksi. Bandung: Penerbit Mizan.

Suharyat, Y. 2009. Hubungan Antara Sikap, Minat, dan Perilaku Manusia. Region, 1 (3), 1-19.

Szymanska, K. \& Palmer. S. 2011. Psikoterapi dan Konseling Kognitif. Dalam Editor Palmer. 2011. Konseling dan Psikoterapi. Yogyakarta: Pustaka Pelajar.

Williams, C. 2000. Being Assertive. Dr C J Williams and University of Leeds Innovations Ltd (ULIS). 